\title{
PENGGUNAAN MEDIA PEMBELAJARAN SASTRA BAGI GURU BAHASA INDONESIA
}

\author{
Asih Riyanti dan Inung Setyami \\ FKIP, Universitas Borneo \\ Jalan Amal 1 Tarakan, Kalimantan Utara \\ email: asihriy anti17@gmail.com
}

DOI: $\underline{10.26858 / \text { retorika.v 10i2.4881 }}$

\begin{abstract}
The Use of Media for Literature Learning for Indonesian Language Teachers. This study aims to describe the use of literary learning media for Indonesian language teachers in Tarakan Junior High School. This research uses qualitative approach. Data obtained through questionnaires, observations, and interviews. Data analysis is done through data reduction, presentation, and inference (conclusions). From the results of research it is found that most of the Indonesian language teachers who teach literature in Junior High School using media audio, visual and audiovisual are limited.
\end{abstract}

\begin{abstract}
Abstrak: Penggunaan Media Pembelajaran Sastra bagi Guru Bahasa Indonesia. Penelitian ini bertujuan mendeskripsikan penggunaan media pembelajaran sastra bagi guru bahasa Indonesia di SMP Kota Tarakan. Penelitian ini menggunakan pendekatan kualitatif. Data yang diperoleh melalui angket, observasi, dan wawancara. Analisis data dilakukan melalui tahap reduksi, penyajian, dan inferensi (penarikan kesimpulan). Dari hasil penelitian ditemukan bahwa sebagaian besar guru bahasa indonesia yang mengajar sastra di kelas VIII SMP menggunakan media audio, visual dan audiovisual secara terbatas.
\end{abstract}

Kata Kunci: bahasa Indonesia, media pembelajaran, pembelajaran sastra

Pembelajaran di sekolah pada saat ini harus disesuaikan dengan perkembangan teknologi informasi sehingga terjadi perubahan dan pergeseran paradigma pendidikan. Kemajuan dan perkembangan teknologi sudah demikian menonjol sehingga penggunaan alat-alat bantu mengajar seperti alat-alat audio,visual serta perlengkapan sekolah disesuaikan dengan perkembangan zaman. Selain itu, pembelajaran harus disesuaikan dengan tuntutan kurikulum sesuai dengan materi, metode, dan tingkat kemampuan belajar siswa. Hal ini bertujuan agar tujuan pembelajaran dapat tercapai secara efektif dan efisien. Namun demikian, Rahmatulloh mengemukakan (dalam Kurniawan, 2013:8) bahwa pemanfaatan media merupakan salah satu dari sekian banyak masalah dalam pembelajaran di sekolah.

Secara umum media dalam pendidikan disebut media, yaitu berbagai jenis komponen dalam lingkungan siswa yang dapat merangsang untuk berfikir (Sadirman dalam Triyanto, Eko, Anitah, dan Suryani, 2013:229). Selanjutnya, Notoamodjo (2003:71) mengemukakan bahwa media pembelajaran adalah alat-alat yang digunakan oleh pendidik dalam menyampaikan bahan pengajaran. Alat bantu ini lebih sering disebut alat peraga karena berfungsi membantu dan memperagakan sesuatu dalam proses pembelajaran.

Tujuan media pembelajaran sebagai alat bantu pembelajaran, yaitu untuk mempermudah proses pembelajaran di kelas, meningkatkan efisiensi proses pembelajaran, menjaga relevansi antara materi pelajaran dengan tujuan belajar, membantu konsentrasi pembelajar dalam proses pembelajaran. Berdasarkan dari tujuan media pembelajaran tersebut, dapat disimpulkan bahwa kehadiran media pembelajaran merupakan hal yang dibutuhkan untuk mempermudah proses pembelajaran. Secara umum media mempunyai 
kegunaan: (1) memperjelas pesan agar tidak terlalu verbalistis, (2) mengatasi keterbatasan ruang, waktu tenaga dan daya indera, (3) menimbulkan gairah belajar, interaksi lebih langsung antara murid dengan sumber belajar, (4) memungkinkan anak belajar mandiri sesuai dengan bakat dan kemampuan visual, auditori dan kinestetiknya, (5) memberi rangsangan yang sama, mempersamakan pengalaman dan menimbulkan persepsi yang sama (Ekayani, 2016:3).

Berkaitan dengan media pembelajaran mata pelajaran bahasa Indonesia, khususnya pembelajaran sastra, selama ini pembelajaran sastra masih terbatas pembelajaran secara teoretis dan tes. Aspek-aspek yang dinilai masih dalam taraf pengetahuan siswa saja. Media pembelajaran sastra hendaknya menekankan pada sisi apresiasi siswa terhadap karya sastra. Oleh karena itu, perlu dikembangkan bentuk-bentuk media pembelajaran yang tepat sasaran dengan memperhatikan tingkatan apresiasi siswa. Adanya perubahan orientasi pembelajaran pada apresiasi, ekspresi, dan produksi sastra mengakibatkan rancangan pembelajaran sastra tidak lagi hanya berpusat pada peningkatan pengetahuan kesastraan siswa yang sifatnya cenderung teoretis dan mengesampingkan praktiknya. Sebagai contoh, peserta didik lebih dituntut untuk menguasai tokoh-tokoh atau sastrawan dari berbagai era dan hasil karya mereka saja tetapi kurang memahami makna atau nilai-nilai yang terkandung di dalam karya satra. Bahkan hal yang memprihatinkan, para siswa kurang dalam praktik pembelajaran sastra, seperti pementasan drama, pantomime, pembacaan puisi, deklamasi puisi, dan musikalisasi puisi.

Sastra sebagai cerminan keadaan sosial budaya bangsa haruslah diwariskan kepada generasi mudanya. Menurut Herfanda (dalam Suryaman, 2010:114), sastra memiliki potensi yang besar untuk membawa masyarakat ke arah perubahan, termasuk perubahan karakter (pen.) Sebagai salah satu jenis kesenian, sastra sudah ada dalam perjalanan peradaban manusia. Proses pendidikan, pengenalan, dan pemahaman terhadap sastra akan dapat memperkaya manusia sebagai pribadi dalam dialog terus menerus dengan dunia manusia dan kemanusiaan (Nurgiyantoro dan Efendi, 2013:383)
Penelitian penggunaan media ini dilakukan dengan asusmsi bahwa penelitian yang relevan, terutama pada pembelajaran di tingkat SMP kurang diperhatikan. Penelitian sebelumnya dilakukan oleh Winarno dan Kusmaryani (2015). Hasil penelitian ini menunjukkan bahwa SD, SMP, SMA Unggulan di Kota Tarakan telah memiliki media pembelajaran pada semua bidang pelajaran baik media pembelajaran audio maupun visual. Media yang paling banyak digunakan adalah LCD, White board, dan buku ajar. Media tersebut difasilitasi oleh pemerintah pusat juga ada bantuan dari pemerintah kota. Namun demikian, semua media yang ada belum digunakan secara maksimal oleh guru. Tidak semua media pembelajaran yang tersedia telah terpakai dalam pembelajaran sehingga hanya tersimpan di laboratorium. Penelitian yang dilakukan Winarno dan Kusmaryani (2015) memiliki persamaan dengan penelitian ini, yakni mengkaji media pembelajaran, namun berbeda pada aspek dan lokasi penelitian. Selain itu, penelitian terdahulu hanya memgkaji media pembelajaran saja, sedangkan penelitian ini fokus pada media pembelajaran sastra. Oleh karena itu penelitian ini dilakukan untuk memperkaya penelitian tentang media pemebajaran sastra.

Penelitian ini bertujuan untuk mendeskripsikan media pembelajaran sastra bagi guru bahasa Indonesia di SMP wilayah perbatasan kota Tarakan. Alasan peneliti memilih SMP di wilayah Tarakan Utara sebagai lokasi penelitian adalah (1) Sekolah SMP di Kota Tarakan wilayah Tarakan Utara berada di wilayah pinggiran dan jauh dari pusat kota sehingga diduga memiiki keterbatasan penggunaan media pembelajaran sastra; (2) sekolah yang diteliti kurang memiliki akses, kelengkapan sarana, dan prasarana sehingga muncul asumsi bahwa sekolah tersebut memiliki keterbatasan penggunaan media pembelajaran sastra. Oleh karena itu, untuk membuktikan asumsi yang sering menjadi pandangan masyarakat luas pada umumnya, khususnya di kotaTarakan, perlu dibuktikan melalui penelitian.

\section{METODE}

Pendekatan dalam penelitian ini adalah penelitian kualitatif dengan desain penelitian deskriptif kualitatif. Dipilihnya rancangan pene- 
litian ini didasarkan atas pertimbangan bahwa (1) penelitian dilakukan dengan latar alamiah, yakni peristiwa pembelajaran; (2) menggunakan manusia sebagai instrumen utama; dan (3) penelitian ini lebih memperhatikan proses daripada hasil. Penelitian ini dilaksanakan di SMP SeKota Tarakan tahun pelajaran 2016/2017. Pelaksanaan penelitian berlangsung selama 4 bulan, yakni April sampai dengan Juli tahun 2017. Populasi penelitian ini adalah keseluruhan SMP di Kota Tarakan yaang berjumlah 19 SMP. Teknik pengambilan sampel yaitu purposive sampling dengan memilih sampel 2 sekolah untuk setiap kecamatan. Jumlah sampel yang terpilih adalah 8 sekolah untuk 4 kecamatan. Semua guru Bahasa dan Sastra Indonesia pada sekolah tersebut diajdikan sebagai subjek penelitian.

Instrumen penelitian yang digunakan mengumpulkan data, yakni lembar cek list ketersediaan media pembelajaran sastra di sekolah, lembar observasi, dan lembar panduan wawancara. Peneliti terjun ke lapangan untuk mengecek media pembelajaran sastra yang tersedia dan digunakan di sekolah, melakukan observasi ke kelas, melihat penggunaan media pembelajaran, dan melakukan wawancara dengan guru tentang media pembelajaran yang digunakan. Analisis data dalam penelitian ini menggunakan tahapan dari Miles dan Huberman yang meliputi kegiatan mereduksi data, penyajian data, dan penarikan kesimpulan.

\section{HASIL DAN PEMBAHASAN}

Berdasakan hasil analisis data yang diperoleh dari 8 SMP, tidak ada sekolah yang benar-benar selalu menggunakan media pembelajaran baik audio, visual, maupun audio visual dalam pembelajaran sastra. Hasil angket yang diperoleh dari guru bahasa Indonesia menunjukkan penggunaan media audio dalam pembelajaran sastra memperoleh nilai rata-rata $20,7 \%$, media visual dengan nilai rata-rata $88,7 \%$, dan audio visul dengan rata-rata $21,9 \%$, dan ada pada saat pembelajaran sastra tidak menggunakan media pemebelajaran dengan rata-rata $38,7 \%$. Data penggunaan media pembelajaran sastra di SMP kota Tarakan ditampilkan secara lengkap pada Tabel 1.

Di SMP Kumi Tarakan, terdapat 1 guru bahasa Indonesia. Berdasarkan angket yang telah diisi oleh Guru Bahasa Indonesia didapatkan bahwa media pembelajaran sastra di SMP
Kumi diajarkan sesuai dengan Kompetensi Dasar yang ada sesuai dengan kurikulum yang berlaku di sekolah. Sementara jenis pembelajaran sastra yang diajarkan, yaitu puisi, prosa, dan drama. Untuk SMP Negeri 3 Tarakan terdapat guru bahasa Indonesia sebanyak lima orang. Guru belum dapat memilih media pembelajaran yang tepat dengan materi, baik audio, visual, maupun audio visual. Di kelas, guru sebatas membelajarkan siswa secara konvensional, misalnya guru di depan kelas sebagai model memperagakan membaca puisi.

Di SMP Negeri 3 Tarakan guru mengajarkan sastra, namun yang diajarkan hanya pembelajaran sastra lama yang berkembang dimasyarakat, seperti puisi rakyat, pantun, syair, gurindam. Guru sering menggunakan metode ceramah dalam menyampaikan materi. Guru menyatakan menggunakan media audio visual, tetapi yang terjadi adalah guru tidak menggunakan media apapun dalam pembelajaran sastra di kelas karena hanya melakukan ceramah dalam menyampaikan materi sastra. Siswa disuruh memperhatikan syarat dan kaidah penulisan pantun. Siswa hanya diminta melakukan kegiatan berbalas pantun tanpa diberi contoh terlebih dahulu atau melihat, mendengar melalui media audio, audio visual, maupun visual. Guru tidak menggunakan media pemebelajaran sastra, meski mengetahui bahwa pembelajaran sastra dengan menggunakan media lebih baik dan efektif.

Guru bahasa Indonesia kelas SMP Negeri 3 Tarakan mengajarkan materi fabel, novel, cerpen, dan puisi. Guru menggunakan media pembelajaran berupa perangkat keras, seperti seperti laptop, maupun LCD. Ini dianggap oleh guru sebagai media audio-visual. Pembelajaran yang diberikan menggunakan media pembelajaran berupa video pembacaan puisi penyair besar dan video fabel. Guru hanya meminta siswa untuk melihatnya saja tanpa ada kelanjutan setelah menyaksikan video tersebut. Guru lebih banyak menyampaikan materi mengunakan metode ceramah dan siswa hanya diminta untuk mengapresiasi karya sastra dan nilai-nilai yang terkandung dalam karya sastra. Guru pernah menggunakan media audio visual dan belum guna mengajarkan sastra sastra. Guru merasa bahwa menggunakan media pembelajaran sastra akan lebih efektif dalam KBM, tetapi guru tidak melaksanakan pembelajaran dengan berbagai media yang sesuai guna memperbaiki dan meningkat- 
Tabel 1 Distribusi Penggunaan Media Pembelajaran Sastra di SMP Kota Tarakan

\begin{tabular}{lcccc}
\hline \multirow{2}{*}{ Sekolah } & \multicolumn{3}{c}{$\begin{array}{l}\text { Media } \\
\text { Pembelajaran }\end{array}$} & $\begin{array}{l}\text { Tanpa Media } \\
\text { Pembelajaran }\end{array}$ \\
\cline { 2 - 4 } & Audio & Visual & Audio visual & \\
\hline SMP Kumi Tarakan & $10 \%$ & $10 \%$ & $20 \%$ & $60 \%$ \\
SMP Negeri 3 Tarakan & $35 \%$ & $20 \%$ & $35 \%$ & $10 \%$ \\
SMP Negeri 7 Tarakan & $30 \%$ & $25 \%$ & $20 \%$ & $25 \%$ \\
SMP Tunas Kasih & $10 \%$ & $20 \%$ & $20 \%$ & $50 \%$ \\
SMP Don Bosco & $10 \%$ & $15 \%$ & $15 \%$ & $60 \%$ \\
SMP Negeri 9 Tarakan & $30 \%$ & $25 \%$ & $25 \%$ & $20 \%$ \\
SMP Negeri 2 Tarakan & $30 \%$ & $25 \%$ & $30 \%$ & $15 \%$ \\
SMP Muhammadiyah Tarakan & $10 \%$ & $15 \%$ & $10 \%$ & $65 \%$ \\
Rata-rata & $20,7 \%$ & $18,7 \%$ & $21,9 \%$ & $38,7 \%$ \\
\hline
\end{tabular}

kan hasil belajar dan minat siswa.

Guru bahasa Indonesia di SMP Negeri 7 mengajarkan aspek sastra: menulis puisi, membuat puisi, menulis cerpen, fabel, dan mengkritik puisi dan cerpen. Namun demikian, penggunaan media belum dilakukan sepenuhnya oleh guru. Guru menggunakan media visual berupa lukisan pemandangan atau lingkungan yang diperlihatkan sekilas oleh siswa di depan kelas. Guru belum mampu menggunakan media berbasis teknologi, seperti media audio-visual, visual, maupun audio. Guru menyatakan bahwa penggunaan media visual dan audio visual sudah efektif karena akan membuat mahasiswa tertarik dan semangat dalam pembelajaran.tetapi belum dilakukan sepenuhnya oleh guru.

Data yang diperoleh dari guru di SMP Tunas Kasih Tarakan menunjukkan bahwa guru belum mampu menggunakan media pada saat pelajaran sastra baik di kelas mapun di luar kelas. Siswa hanya diminta untuk menyaksikan drama, namun selanjutnya tidak dijelaskan apa yang harus dikerjakan oleh siswa. Hal ini merupakan bentuk ketidakpahaman guru akan media pembelajaran yang digunakan meski tahu bawa penggunaan media lebih efektif dari pada dengan metode ceramah. Data yang diperoleh dari guru di SMP Tunas kasih pada siswa kelas IX menujukkan bahwa guru tidak menggunakan media pembelajaran dengan baik. Hanya media audio visual untuk menyaksikan drama di kelas dan siswa diminta untuk menyimak.

Dari hasil pengamatan ketersediaan media pembelajaran sastra yang digunakan oleh guru Bahasa Indonesia di SMP Don Bosco dapat diuraikan bahwa di SMP Don Bosco terdapat 2 guru bahasa Indonesia yang mengajarkan pembelajaran sastra. Guru bahasa Indonesia di SMP
Don Bosco mengakui bahwa dengan media pembelajara siswa tertarik dan mudah memahami yang disampaikan oleh guru. Namun demikian, guru dalam kegiatan mengajar sastra tidak menggunakan media pembelajaran.

SMP Negeri 9 diketahui bahwa hampir semua guru bahasa Indonesia di SMPN 9 menggunakan media pembelajaran saat melakukan kegiatan belajar mengajar sastra di kelas. Pembelajaran sastra disesuaikan dengan kompetensi dasar dan materi pembelajaran. Pembelajaran sastra tersebut berupa cerpen, puisi, novel dan dongeng. Media pembelajaran sastra yang digunakan oleh guru Bahasa Indonesia di SMPN 9, yaitu jenis visual (teks) berupa buku teks (buku cerpen, buku puisi, novel, dan buku cerita rakyat). Guru mengakui bahwa dengan media pembelajaran dalam kegiatan belajar mengajar di kelas dapat mempermudah dalam menyampaikan materi dan siswa lebih tertarik dalam mengikuti pembelajaran yang disampaikan oleh guru di kelas.

Guru di SMP Negeri 2 Tarakan mengetahui bahwa penggunaan media pembelajaran lebih efektif dari pada tidak menggunakan media pembelajaran.Namun demikian, penggunaan media tidak dilakukan dengan maksimal, lebih banyak menggunakan ceramh pada saat meyampaikan materi. Di SMP N 2 terdapat 5 guru mengajar Bahasa Indonesia. Sebagian besar guru menggunakan media LCD dan rekaman pembacaan puisi (audio-visual).

\section{Pembahasan}

Pembahasan penelitian ini mencakup gambaran penggunaan media pembelajaran untuk pembelajaran sastra di SMP Kota Tarakan. Berdasarkan data yang telah dipaparkan sebe- 
lumnya terlihat bahwa sebagia besar guru SMP di Tarakan belum menyadari sepenuhnya manfaat media pemebelajaran. Hal ini tampak jelas dari masih banyaknya guru yang belum menggunakan media pembelajaran dalam menyampaikan materinya $(38,7 \%)$. Angka ini menunjukkan masih banyak guru yang belum menggunakan media pembelajaran.

Pembelajaran sastra pada dasarnya sangat membutuhkan media dalam proses pembelajarannya. Media di sini dapat berupa apa saja, yang dapat membantu penyampaian materi pembelajaran. Notoamodjo (2003:71) mengemukakan bahwa media pembelajaran adalah alat-alat yang digunakan oleh pendidik dalam menyampaikan bahan pengajaran. Sebagai contoh, dalam mengajarkan kompetensi membaca puisi, salah satu media yang dapat dimanfaatkan adalah media audiovisual. Media ini dapat digunakan oleh guru untuk memberikan contoh pembacaan puisi yang baik yang dilakukan olehsastrawan. Melalui media ini guru akan terbantu menjelaskan cara membaca puisi yang baik sesuai yang ditampakkan oleh media audio-visual. Begitupula dalam pembelajaran sastra yang lain, media pembelajaran hadir untuk memudahkan proses pembelajaran. Hal ini senada dengan yang dikatakan oleh Degeng (1993) yang mengungkapkan bahwa terdapat beberapa manfaat penggunaan media pembelajaran, yaitu: (1) pengajaran akan lebih menarik perhatian siswa sehingga dapat menumbuhkan motivasi belajar; (2) bahan pengajaran akan lebih jelas maknanya sehingga dapat lebih dipahami oleh siswa; (3) metode mengajar akan lebih bervariasi; dan (4) siswa melakukan kegiatan belajar, seperti mengamati, melakukan dan mendemonstrasikan.

Gambaran penggunaan media pembelajaran sastra SMP di kota Tarakan menunjukkan bahwa guru pada dasarnya sudah memahami arti penting penggunaan media pembelajaran. Na-

\section{DAFTAR PUSTAKA}

Degeng, I Nyoman Sudana. 1993. Media Pendidikan. Malang: FIP IKIP Malang.

Ekayanti, Ni Luh Putu. 2016. "Pentingnya Penggunaan Media Pembelajaran untuk Meningkatkan Prestasi Belajar Siswa". Bali: Jurnal PGSD FIP Universitas Pendidikan Ganesha. Online. https://www.researchgate.net/publication/3151 05651, diakses: 29 Desember 2017. mun demikian, masih terdapat guru yang tidak menggunakan media pembelajaran dikarenakan tidak paham menggunakan media ataupun tidak peduli terhadap penggunaan media. Beberapa guru yang telah menggunakan media pembelajaran juga belum maksimal. Terdapat beberapa guru yang hanya menampilkan media yang digunakan tanpa memahami prosesdur pemanfaatan media untuk memudahkan siswa dalam melakukan kegiatan ataupun memahami materi. Beberapa hal yang perlu diperhatikan dalam menggunakan media pembelajaran: (1) efektivitas dan efisiensi, (2) relevansi, dan (3) produktivitas (Musfiqon, 2012:116). Musfiqon menambahkan kriteria pemilihan media, yakni (1) keseusaian tujuan, (2) ketepatgunaan, (3) keadaaan peserta didik, (4) ketersediaan, (5) biaya kecil, dan (6) keterampilan guru.

\section{PENUTUP}

Dari data yang diperoleh terdapat tiga macam media pembelajaran yang digunakan oleh guru di SMP Kota Tarakan, yaitu media visual, audio, dan audiovisual. Dari delapan sekolah yang diajadikan sampel, sebanyak $20,7 \%$ guru menggunakan media audio, $18,7 \%$ guru menggunakan media visual, $21,9 \%$ guru menggunakan media audiovisual, dan $38,7 \%$ guru tidak menggunakan media dalam proses pembelajaran. Dari data tersebut dapat disimpulkan bahwa penggunaan media penggunaan media pembelajaran belum sepenuhnya dimaksimalkan oleh guru. Dari hasil observasi dan wawancara, sebagian besar guru di sekolah mengetahui dan menyadari pentingnya penggunaan media pembelajaran sastra. Namun demikian, tidak semua guru pada setiap sekolah menggunakan media pembelajaran tersebut.

Kurniawan, A.D. 2013. Metode Inkuri Terbimbing dalam Pembuatan Media Pembelajaran Biologi untuk meningkatkan Pemahaman Konsep dan Kreativitas Siswa SMP. Jurnal Pendidikan IPA Indonesia, 2(1): 8-11.

Musfiqon. 2012. Pengembangan Media dan Sumber Pembelajaran. Jakarta: Prestasi Pustakaraya.

Notoatmodjo, S. 2003. Pengembangan Sumber Daya Manusia. Jakarta: PT. Asdi Mahasatya. 
Nurgiyantoro, Burhan dan Anwar Efendi. 2013. Prioritas Penentuan Nilai Pendidikan Karakter dlam Pembelajaran Sastra. Jurnal Cakrawala Pendidikan, 3:382-393.

Suryaman, Maman. 2010. Pendidikan Karakter Melalui Pembelajaran Sastra. Cakrawala Pendidikan, 21, 112-116.
Triyanto, T., Sri Anifah, dan Nunuk Suryani 2013. Membuat Media Pembelajaran yang Menarik. Jurnal Ekonomi \& Pendidikan, 8(1): 19-35.

Winarno dan W. Kusmaryani. 2015. Analisis Penggunaan Media Pembelajaran bagi guru SD, SMP, SMA Unggulan di Kota Tarakan. Tarakan: LP2M. 